\title{
DIÁLOGOS INTERMÍDIAS, OU POLÍTICA DE IDENTIDADES EM SALA DE AULA
}

\section{INTERMEDIA DIALOGUES, OR IDENTITY POLITICS IN THE CLASSROOM}

\section{Daniel Nascimento Silva*}

\section{RESUMO}

Este artigo reflete sobre uma experiência didática com alunos de Letras, a quem ministrei, no Rio de Janeiro, a disciplina Diálogos Intermídias, em 2011. Partindo do princípio de que as palavras significam porque podem se descontextualizar (BAUMAN \& BRIGGS, 1990) ou se deslocar de seus contextos "originais" (DERRIDA, 1977) - isto é, significam porque viajam -, a disciplina investigou a viagem de signos entre campos teóricos diversos: da literatura para a clínica, da etnografia para a literatura, das favelas para a universidade. $\mathrm{O}$ ponto central é que o ensino e a aprendizagem que se desenrolaram no centro da cidade do Rio de Janeiro, ou no centro carioca (karaî’oca significa 'casa de branco' em tupinambá), não foram atividades de cognição humana, mas de condição humana - isto é, para além de meras questões cognitivas na relação linguagem-ensino, o que se desvelou nessa relação foi a emergência de posicionamentos humanos particulares (RAJAGOPALAN, 2002). Numa perspectiva da mútua constituição entre linguagem e sociedade, investigo posicionamentos identitários que emergiram na leitura e em comentários sobre textos que descontroem versões dominantes de gênero, sexualidade, raça e subjetividade.

Palavras-chave: contexto; descontextualização; identidade; ensino; leitura.

\section{ABSTRACT}

This paper reflects upon a didactic experience with students who took the Intermedia Dialogues, a class that I taught in Rio de Janeiro in 2011. Starting from the principle that words mean what they mean because they can decontextualize themselves (BAUMAN \& BRIGGS, 1990) or move beyond their "original" contexts (DERRIDA, 1977) - i.e., they mean because they "travel," the discipline investigated how signs traveled within different theories: from fiction to clinic, from ethnography to fiction, from the favelas to the university. The main point here is that both teaching and learning that unfolded in that context, in the center of Rio de Janeiro, or the Carioca center (karai' oca means 'the house of the white' in Tupinamba language) was not properly an activity of human cognition, but of human condition - i.e., beyond mere cognitive issues in the language-teaching relation, this very relation rendered the emergence of particular human dispositions (RAJAGOPALAN, 2002). In following a perspective that takes language and society to be mutually constitutive,

\footnotetext{
*UNIRIO, Rio de Janeiro (RJ), Brasil. dnsfortal@gmail.com
} 
I scrutinize the identity claims that emerged in the ways students read and commented on texts that deconstruct dominant versions of gender, sexuality, race and subjectivity.

Keywords: context; decontextualization; identity; teaching; reading.

\section{INTRODUÇÃO}

Crescimento econômico, acesso de novas classes a bens de consumo e cultura antes restritos a poucos, mudanças na educação ${ }^{1}$. O país que sempre se disse almejar o futuro reformula seu discurso. O Brasil é o país do agora. Tal como certo refrigerante de coca, que Rodrigo S. M., heterônimo de Clarice Lispector (1998a), ironicamente diz ter "gosto do cheiro de esmalte de unhas, de sabão Aristolino e plástico mastigado", o Brasil "é hoje" (p.23). Patrocinadora da escrita de Rodrigo S. M., e não lhe havendo pago nada por isso, "essa bebida que tem coca é hoje. Ela é um meio de a pessoa atualizar-se e pisar na hora presente" (p.23). No Brasil, o futuro acabou de começar. Durante a escrita deste texto, chegou até mim o anúncio de um seminário sobre publicação de artigos em periódicos "de impacto", leia-se, periódicos escritos em língua inglesa. "Brazil is rapidly becoming a regional and international research leader" ${ }^{\prime 2}$. Inevitável não identificar certo tom imperialista nesse discurso do presente. Não basta o futuro já ter chegado, é necessário ser líder. Não basta produzir boa ciência, é preciso competir.

Em meio a mudanças econômicas de várias ordens, eu, professor de Linguística, deparo com subjetividades que se constituem nessa chegada do futuro. Refiro-me a um grupo de dez alunos de graduação do curso de Letras da UNIRIO, para quem ministrei, entre agosto e dezembro de 2011, a disciplina Diálogos Intermídias. Eles serão aqui nomeados ficticiamente pelos heterônimos Alice, Alex, Bia, Bruno, Cauã, Lia, Nina, Otto, Sabrina e $\mathrm{Xia}^{3}$. A mim foi designada a tarefa de ministrar uma disciplina intermídias, o que tem a ver com a própria feição do novo curso de Letras da UNIRIO, iniciado em 2010. Nascido num departamento de teoria do teatro e formulado por professores que estão ligados à produção teatral e musical, o curso tem, assim, um desenho diferenciado, na medida em que dialoga com outras mídias,

1 Gostaria de agradecer aos dois pareceres anônimos de Trabalhos em Linguística Aplicada. As críticas e sugestões contribuíram para que eu observasse e mexesse em alguns pontos fracos deste texto. As eventuais falhas que tiverem permanecido são de minha inteira responsabilidade.

2 Primeira linha do texto de apresentação do Second Brazilian Meeting on Research Integrity, Science and Publication Ethics, realizado na UFRJ em 2012 (http://www.iibrispe.coppe.ufrj.br, acesso $4 / 5 / 2012)$.

3 Solicitei aos alunos permissão para divulgação do áudio das aulas e também lhes pedi que sugerissem heterônimos. 
aquelas concernentes ao espaço do teatro, à imagem-movimento do cinema, ao som da música, às vozes da filosofia, ao texto etnográfico da antropologia.

Ao falar de "subjetividades que se constituem nessa chegada do futuro", trato mais especificamente dos efeitos de um dos programas criados em tempos de crescimento econômico, o Programa de Expansão das Universidades Federais - Reuni, nas políticas de identidade nada tranquilas da cidade do Rio de Janeiro. Por princípio, o Reuni é um programa para as periferias - ele visa à ampliação das universidades em campi fora dos centros urbanos tradicionais ou a criação de cursos noturnos nos campi já existentes nesses centros tradicionais. Este último é o caso da criação do curso de Letras da UNIRIO. Temos, assim, uma ampliação do centro, em direção a um horário, digamos, periférico, o período noturno.

Gostaria de lembrar, antes de formular o problema que subjaz a esta reflexão, que o nome 'carioca' vem da locução tupinambá karai'oca, ou 'casa de branco'. Essa pista etimológica irá nos ajudar a pensar a política de identidades em questão, situada na zona sul do Rio, metrópole anunciada em muitos discursos como o cartão postal do Brasil e que constitui, como nos lembra Adriana Lopes, "a sede da mestiçagem racial brasileira, que sempre teve como donos e patrões 'os homens brancos" (2011, p.17).

Assim, este artigo visa relatar uma experiência de ensino nesse contexto específico. Mais especificamente, o que se propõe aqui é discutir como, na condução do curso, instauraram-se, entre alunos e professor, pontos de crise, reivindicações de afetos e construções políticas de identidades. O programa desse curso intermídias, que discutirei logo a seguir, pautou-se nesse trânsito de signos e identidades, uma complexa circulação de ideias e vozes a partir da leitura de textos de gêneros e disciplinas diversos e do debate sobre esses textos.

O que acontece quando a voz do subalterno viaja do seu contexto de origem, faz escala em estudo etnográfico e aterrissa em contexto acadêmico do centro? Como lidar com o silêncio ou com as lágrimas de alguns alunos que se impactaram com a circulação de discursos constituídos e deslocados pelo horror do holocausto? Como tratar de textos que extraem da ficção o material para tratar a realidade social e psíquica do sujeito? Como pensar na relação entre educação e crise num momento em que o Brasil se diz progredindo e em que as vozes subalternas continuam silenciadas? A sequência deste texto é um convite a que o/a leitor/a examine comigo estas e outras questões. 


\section{DIÁLOGOS INTERMÍDIAS}

O ponto central de minha argumentação é que a experiência descrita a seguir aponta para o fato de que ensinar e aprender não são atividades que aconteçam desvinculadas da reivindicação de certos modos de se vincular ao mundo. Dito de outro modo, o contexto particular de ensino e aprendizagem que ora descrevo vincula-se a uma política de identidades ${ }^{4}$. A conversa sobre os textos e imagens que marcou as sextas-feiras à noite na Urca não foi exatamente uma atividade de educação como cognição, mas como condição humana. O recurso a textos que apontassem para possibilidades radicalmente novas de dizer o sujeito e suas atividades de significação procurou substituir, assim, o cogito ou pensar desencarnado pela conditio de pessoas situadas numa cidade específica, dividida por fronteiras simbólicas com raça, gênero e sexualidade. As perguntas sobre aprender e ensinar num contexto como esse são, assim, atravessadas por pontos de tensão e conflito, sinalizações de crise e crítica, reivindicações de afeto e elaborações de pertencimento - i.e., a problematização desta experiência de ensino aponta para uma política de identidades.

Antes de delinear esse modo radicalmente político de encarar o conhecimento que ali se produziu, convém contextualizar a disciplina em questão e o fio condutor das discussões. A disciplina Diálogos intermídias faz parte da grade curricular do curso de Letras da UNIRIO. Como mencionei anteriormente, esse curso tem como

\footnotetext{
4 A identidade é uma questão antiga. Perguntas como "quem sou eu?", "qual o sentido de minha existência nesse mundo?" ocupam filósofos e cientistas há muito tempo. Pode-se atribuir a formulação lógica do conceito de identidade à filosofia de Aristóteles, que dá sustentação formal para o princípio do discurso verdadeiro sobre o ser, já enunciado em diálogos platônicos tais como o Sofista ou Teeteto. Esse discurso é aquele que embasa uma concepção substancial de indivíduo, cuja perspectiva (linguística) de si e do mundo refletiria uma realidade anterior e exterior, independente da enunciação linguística da identidade. Assim, Platão postula, no Sofista, que "sempre que há fala, ela deve ser sobre algo. É impossível que ela não seja sobre algo" (PLATÃO, 360 A. C.: 262e). O discurso (identitário) seria então sobre algo, o que se daria de modo falso ou verdadeiro. Isto é, um enunciado como 'Teeteto está sentado', se comparado com a realidade, pode ser dela uma boa representação, sendo portanto verdadeiro; pode também não corresponder à realidade, como em 'Teeteto voa', sendo então falso (os exemplos são de Platão). No tratado Da interpretação, Aristóteles dirá que toda sentença tem significado, mas apenas as proposições (i.e., os enunciados com valor de verdade) podem ser verdadeiras ou falsas. As sentenças que não são verdadeiras ou falsas (e.g. uma oração ou promessa) são assim excluídas do domínio da lógica e delegadas à retórica ou à poesia. No século passado, Austin (1962) demonstrou que verdade e falsidade não são as características fundamentais dos discursos, mas sim a performatividade - i.e., a ação sobre o mundo. Um enunciado performativo, como 'eu vos declaro marido e mulher', pronunciado por um sacerdote no universo heterossexual cristão, não representa uma realidade anterior, mas opera, realiza o ato de casar. Isso terá consequências sem volta para o pensamento sobre a identidade - hoje, as identidades são vistas como performances, atos que linguisticamente instituem sua referência no mundo, em vez de meramente descreverem ou constatarem um estado de coisas anterior e exterior.
} 
proposta fazer dialogar questões de linguagem e literatura, típicas das graduações de Letras, com questões de teatro, música, mídia e filosofia, um tanto incomuns na tradição de cursos de Letras. Conforme o projeto pedagógico do curso, a disciplina Diálogos Intermídias consiste em seminários em torno das "relações entre literatura e imprensa, palavra e imagem, linguagens verbais e linguagens audiovisuais" (WERNECK ET AL, 2009, p.44). Diante da tarefa de ministrá-la e sabendo da abertura dos alunos às relações entre palavra e imagem, planejei um conjunto de seminários "entre-mídias". Modelei o curso a partir da noção de transmutação ou tradução intersemiótica, proposta por Jakobson (1961). Segundo o linguista russo, acontece uma transmutação toda vez que signos verbais são interpretados "por meios de sistemas de signos não-verbais" (JAKOBSON, 1961, p.65). Na classificação que Jakobson oferece para o ato de traduzir, a transmutação é a tradução intermídia por excelência, uma vez que as duas outras modalidades, a tradução intralingual ou reformulação (rewording) e a tradução interlingual ou "tradução propriamente dita" acontecem, respectivamente, dentro de uma mesma língua ou entre línguas. A transmutação é o processo mais amplo e não puramente verbal que envolve atos tradutórios como, por exemplo, a adaptação de uma obra literária para o cinema.

Planejei então um conjunto de seminários intersemióticos ou intermídias, distribuídos em seis seções. A primeira discutiu o referido texto clássico de Jakobson e a sua desconstrução por Derrida (2002). Analisamos a transmutação do romance As horas, de M. Cunninghan para o cinema, por S. Daudry. Depois, partimos para a psicanálise. O texto selecionado foi o ensaio O Estranbo, que Freud publicou em 1919. O estudo é preparatório para sua teoria sobre a melancolia (o afeto contemporâneo seria a depressão). Freud assume aqui um método intermídia: ele inicia seu estudo sobre o afeto do estranho na literatura e no uso da língua, e apenas depois parte para formulações clínicas. Lemos também o conto $\mathrm{O}$ bomem da areia, de E. Hoffmann, de onde Freud extrai muitas de suas elaborações sobre o estranho. A seção seguinte investigou a viagem de signos antropológicos para a literatura e para o cinema. Tratamos da problemática do romance Cidade de Deus, de Paulo Lins. O autor, natural da comunidade Cidade de Deus, foi, quando aluno de graduação, bolsista de pesquisa de Alba Zaluar, e colaborou com sua conhecida etnografia. Depois da escrita de relatórios acadêmicos, Lins dedica-se à literatura e elabora um romance repleto de vozes e hibridismos de gêneros, cujos limites discutimos a partir do filme homônimo de Fernando Meireles e da crítica de Nagib (2006).

Na quarta seção, continuamos com o tema da etnografia em favelas e analisamos o livro Funk-se quem quiser no batidão da cidade carioca, de Lopes (2011). Estudamos mais 
especificamente o modo como os signos cantados, falados e escritos do funk viajam dos morros cariocas para estudos acadêmicos e para a mídia corporativa. Na seção seguinte, discutimos o tema da educação, e lemos o ensaio "Educação e crise, ou As vicissitudes do ensinar", de Shoshana Felman (2000), que nos indaga sobre a relação entre trauma e educação. Investigamos em seguida as noções de crise e educação transformadora no filme Entre os muros da escola, de Laurent Cantet. Na última seção, elegemos o tema do pós-humano. Se o sujeito do humanismo está em crise, a própria noção de sujeito ou ator humano precisava ser indagada. Assim, lemos a crítica de Haraway (2009) à ideia moderna de subjetividade e sua proposta, formulada com base no cinema, na literatura e em outras mídias, de um modelo radicalmente outro de conceber o sujeito humano. Analisamos então o filme $A$ mosca, de David Cronemberg e algumas cenas de Blade Runner, de Ridley Scott, em que a figura do agente humano é transfigurada a partir de sua metamorfose com o animal e a máquina.

\section{EDUCAÇÃO COMO CRISE}

Esta seção invoca a relação entre trauma e educação. O conceito de trauma é fundamental em psicanálise. A palavra 'trauma' em grego significa literalmente "ferida" e deriva do grego antigo trisosko, que significa "furar" (MALABOU, 2012, p.6). A semiologia do trauma indica que ele se caracteriza como "choque que força a abertura ou fura uma barreira protetiva" (ibidem). Freud, que desenvolveu sua teoria sob o horror das duas grandes guerras, conhecia muito bem, como neurologista e como psicanalista, o papel do trauma no aparato psíquico. Para ele, a mera fisicalidade do trauma não seria suficiente para uma afetação do aparelho psíquico. Assim não segue que um trauma ou choque físico impliquem diretamente uma neurose. Algum conflito entre o eu e pulsões se faz necessário para que emerja uma neurose (Freud, 1919b e 1920). O trauma psíquico passa então a ser entendido por Freud "como o influxo de excitação que abala a capacidade metabólica do aparato psíquico" (MALABOU, 2012, p.7).

A inferência que eu gostaria de trazer dessa incursão na psicanálise é que alguma interpretação deve estar presente para que um fenômeno traumático seja propriamente psíquico. Catherine Malabou postula que a psicanálise é um campo que vincula o incidente a uma significação. Ela nos lembra da leitura de Paul Ricoeur, para quem cada acontecimento, em psicanálise, é a junção de uma causa energética com outra hermenêutica, ou do "não-sentido" com o "sentido" (p.5). O que a 
significação ou interpretabilidade do trauma pode nos ensinar sobre a educação? Qual o lugar da crise no ensino? Ou, como pergunta Felman (2000, p.13): "Pode o trauma instruir a pedagogia, e pode a pedagogia lançar luz sobre o mistério do trauma?"

Planejei que o trauma fosse trazido como tema nas semanas finais do curso, quando leríamos o ensaio de Felman. A essa altura, já teríamos lido O Estranbo. Também esperava que o afeto como toque ou afecção tivesse se dado ao longo dos primeiros meses. Exploro aqui tanto a significação ordinária de afeto (como afetividade) como a significação filosófica de afeto como afecção ${ }^{5}$.

As lágrimas confessas de uma aluna foram um sinal para mim de que alguma crise ou catarse estava acontecendo. Como avaliação da leitura do ensaio de Felman, pedi que alguns alunos reagissem por escrito. Alice decidiu escrever um texto-resposta ao ensaio. Trocamos alguns e-mails ao longo de sua leitura. No primeiro, ela me pedia uma extensão do prazo, porque o ensaio se mostrara "mais difícil do que o esperado". Algumas horas depois, recebo outro e-mail com a seguinte confissão: "Estou aos prantos aqui lendo um ensaio teórico, inacreditável... definitivamente o texto é muito bom! Muito obrigada! Sexta entrego." Essas breves linhas me afetaram. Eu também havia chorado ao ler esse ensaio - algo de que não me recordo em minha formação mecanicista. Lembro-me de ter chorado diante da transformação presente no relato da autora. Felman dá testemunho de um curso por ela ministrado em Yale, em 1984, para um grupo multidisciplinar de alunos. A classe estudou o trauma na teoria e na literatura e depois assistiu a testemunhos de sobreviventes do Holocausto, para finalmente fazer sentido da experiência em relatos orais e escritos. No seu testemunho, diz a autora:

\begin{abstract}
eu não sabia que, um dia, eu própria teria de articular meu testemunho sobre aquela classe, cujas aulas - e cujos acontecimentos imprevisíveis - acabaram tornando-se bastante inesquecíveis, tanto para os estudantes, quanto para sua professora, mas de maneira imprevisível para ambas as partes. Nunca tinha dado - e nunca mais dei um curso como este e nunca fiquei tão estupefata diante das lições inesperadas e dos efeitos incalculáveis do ensino, como com a experiência desse curso. Gostaria de narrar esta experiência pedagógica extraordinária como meu próprio "testemunho de vida", para misturar agora a história peculiar daquela classe real, cuja narrativa, apesar de sua peculiaridade única, eu proporei como uma história (...) genérica (testemunhal) (FELMAN, 2000, p.19-20).
\end{abstract}

\footnotetext{
5 A questão da afecção perpassa a história da filosofia. Um modo de entender os afetos ou afecções é pela via metafórica do toque (DERRIDA, 2000). O toque é certamente crucial em filosofia, pois ele acarreta uma relação ética do sujeito com o outro: o sujeito tocaria a si mesmo (auto-afecção), como certa tradição da filosofia advoga? Esse toque viria de fora (hetero-afecção)? Ou o toque viria de dentro, um dentro contendo o outro em mim (auto-hetero-afecção)?
} 
É possível reconhecer no relato de Felman (2000, p.20) um princípio psicanalítico: o testemunho do curso é a "história de como [ela], de fato, [se] torn[ou] uma testemunha do choque comunicado pelo tema (ênfase acrescida)". O incidente dá lugar ao relato. O choque é, segundo Felman, uma condição de possibilidade do ensino. Como condição necessária, ele diferencia 'ensinar' de 'transmitir'. Pautada no próprio choque dos eventos imprevisíveis e inesquecíveis que iria presenciar, a professora chega a uma conclusão contundente quanto ao que seja ensinar:

\footnotetext{
ensinar, em si mesmo, ocorre apenas através de uma crise: se o ensinar não se depara com uma espécie de crise, se ele não encontra nem a vulnerabilidade nem a explosividade de uma dimensão crítica e imprevisível, ele provavelmente não ensinou verdadeiramente: ele talvez tenha transmitido alguns fatos, transmitido algumas informações e alguns documentos (FELMAN, 2000, p.67).
}

A meu ver, a dimensão da crise e do choque, naquele curso, estava na passagem da literatura e da teoria para o real do testemunho de dois sobreviventes do Holocausto. Felman selecionou dois testemunhos, de uma mulher e de um homem, dos vários que ela assistiu no Video Archive for Holocaust Testimonies de Yale. Por questões de espaço, comentarei brevemente o testemunho da mulher. Remeto o/a leitor/a ao texto de Felman para a força literária e testemunhal das duas narrativas.

A mulher relata como sobreviveu ao campo de concentração. A partir dos 15 anos, "a testemunha teve de viver as sucessivas mortes de praticamente todos os membros de sua família - seu pai, sua mãe, seu irmão mais novo, sua cunhada e um bebê (os últimos três morreram em seus braços) (FELMAN, 2000, p.5657)". Seu único laço familiar que sobreviveria ao horror seria seu recém tornado marido, ele também o único sobrevivente de sua família. Os dois "miraculosamente se reencontram depois da libertação". A mulher conta que os dois precisaram ficar juntos depois da guerra porque "ele sabia quem eu era" (apud FELMAN, 2000, p.57). Ambos se transformaram depois do real do evento - ao se reencontrarem, nenhum deles era "mais a mesma pessoa". Talvez precisamente por isso necessitavam mais ainda um do outro: "ele era a única pessoa que sabia... Ele sabia quem eu era, e eu sabia quem ele era... E nós estamos aqui, nós estamos aqui para lhe contar a história". A sobrevivência da mulher era seu único modo de desafiar Hitler. Assim ela testemunha a morte do irmão, em seus braços:

Ele estava pra fazer $13 \ldots$ E, você sabe, quando meu irmão morreu em meus braços eu disse a mim mesma, "Eu vou viver". Decidi desafiar Hitler. Não me entregarei. Porque ele quer que eu morra, vou viver. Esta era a nossa forma de contra-atacar. 
Depois de ter sido libertada, um médico russo me examinou e disse: "Você não teria sobrevivido sob circunstâncias normais... para a medicina é um milagre você ter sobrevivido". Mas eu contei a ele que eu queria realmente viver e disse a mim mesma, "quero viver um dia depois de Hitler, um dia depois do fim da guerra"... E estamos aqui para lhe contar a história.

No testemunho acima, lê-se que o "eu" não termina na superfície do próprio corpo. A mulher estava determinada a sobreviver, e isso foi a maneira deles de lutar contra Hitler. Ela disse a si mesma que iria sobreviver um dia depois de Hitler, e eles estão ali para contar a história. A testemunha é constituída num nós que não se encerra naqueles que viveram o real do holocausto - a extensão vai também até aqueles que assistem ao seu testemunho, todos aqueles que são endereçados por esse relato pungente.

Após apresentar esse primeiro vídeo aos alunos, Felman percebeu que "a classe entrou em crise" (p.59). A exibição foi acompanhada de um silêncio geral, que se transformou em fala além dos limites da aula. Eles a procuravam por telefone, nos horários menos usais do dia e da noite. Recebeu cartas de alunos e de amigos de alunos. A única coisa que Felman podia fazer era "escutar". E enquanto "escutava eles se descarregarem, [ela se deu] conta de que a classe estava se sentindo perdida, desorientada e desenraizada" (p.60). De meu lado, tinha diante de mim uma aluna que ficara em silêncio por alguns dias depois de um e-mail relatando um choro. O texto-reação de Alice viria alguns dias depois, em outro e-mail, desta vez sintomaticamente intitulado "Uma fala emudecida":

\footnotetext{
Professor, esse agradecimento sem palavras é pelo contato com o texto, pela possibilidade, por extrapolar pra dentro e pra além dos limites da disciplina. Fico muito feliz de ter uma leitura como a sua dentro do nosso curso, é imprescindível e traz toda a vitalidade dessa interdisciplinaridade, desse multissigno, desse lugar de crise frente ao qual vc sempre nos coloca. E já que meio mudo, com anseio de fala, o agradecimento vira promessa de abraço - que quero muito dar.
}

A literatura linguístico-antropológica trataria este tipo de comentário ao texto de um evento metapragmático (SILVERSTEIN, 1993): o e-mail funciona como uma pista contextualizadora do texto-reação (o evento pragmático por excelência). Um evento metapragmático tem um valor fundamental, porque ele indica como a pragmática do discurso deve ser tomada, enquadrada, regimentada. O e-mail "emudecido", o agradecimento "sem palavras" de Alice veio se somar à minha crise pessoal: se por um lado confirmava que incluir o choque (queer, feminista, testemunhal, filosófico, linguístico, pragmático, nordestino, racial) estava causando reações imprevisíveis e benéficas, também me indagava pelo papel ético de trazer o 
choque para sala de aula: "esse lugar de crise frente ao qual [eu] sempre [os] coloco". No e-mail de Alice, a junção entre o energético e o hermenêutico está precisamente nesse território "mudo, com anseio de fala". Esse estado limítrofe entre mutismo e fala não descreve nem representa nada, não é constativo; ao contrário, é performativo, i.e., opera, cria, realiza: "o agradecimento vira promessa de abraço". Uma promessa não representa coisa alguma fora dela mesma: ela institui sua própria referência no momento de sua enunciação e vincula prometedor/a e prometido/a (ver AUSTIN, 1962). A promessa de Alice é de um abraço. Filosoficamente, estamos diante da instituição do toque ou afecção pela via performativa, pela invenção de identidades como resultado de uma necessária crise que coloca, aluna e professor, diante do inesperado e do performativo, diante do diálogo com a alteridade como condição fundamental para essa pedagogia da crise.

A crise de Alice, assim como a de G.H., personagem de A paixão segundo G.H., é um ato que se estende ao Outro: "estou procurando, estou procurando. Estou tentando entender. Tentando dar a alguém o que vivi mas não sei a quem (...)" (LISPECTOR, 1998b, p.11). Incognoscível, esse Outro do momento de crise é, no entanto, inevitável: "Estou tão assustada que só poderei aceitar que me perdi se puder imaginar que alguém me está dando a mão" (p.17). Peço, então, a mão de quem me lê para percorrer outros aspectos da crise neste relato de ensino, os quais apontam para outras tensões no ensinar.

\section{OUTRAS CRISES}

A outra crise que eu gostaria de relatar aconteceu no último dia de aula, quando fiz uma avaliação da disciplina com os alunos. A tensão diz respeito à emergência de significados raciais, geográficos e sexuais e a consequente marcação de pertencimento identitário em torno dos textos O Manifesto Ciborgue e Funk-se quem quiser. Após fazer meu próprio relato do que achei do curso e de meu desempenho, pedi que os alunos fizessem o mesmo. Eles, além disso, leram em voz alta para a turma as provas que haviam feito na semana anterior. Uma calorosa discussão, para não dizer um conflito, se iniciou na sala após Nina, uma das alunas, ter manifestado sua opinião sobre a questão de um suposto feminismo no funk carioca. Ela primeiramente leu sua resposta a uma questão da prova, em que eu perguntava se o funk - analisado de modo intermídia por Adriana Lopes - de fato era feminista ou se mantinha a lógica da dominação masculina. Segundo Nina, o chamado funk putaria, ao trazer a voz da mulher que fala abertamente sobre seu corpo e sobre sexo, não é feminista. Eis um trecho de sua prova: 
$\mathrm{Na}$ análise detalhada de suas performances e seus respectivos atos de fala - em shows, apresentações, letras de música - percebemos que o funk, apesar de subverter e alterar muitos significados de gêneros (os homens rebolam; as mulheres tomam a iniciativa sexual e falam abertamente de suas conquistas sexuais e desejos) - não se configura em uma real resistência; ou sequer uma plataforma de mudanças. Essa conclusão é reiterada também pela incursão da autora nos bastidores do mundo da produção cultural do funk, onde percebemos definitivamente que os significados passados pela performance dessas mulheres raramente são reais no âmbito de suas vidas pessoais; em sua maioria, são simplesmente mulheres casadas, cujo funk é modo de ganhar dinheiro e pronto, agenciadas por seus maridos ou irmãos.

Metapragmaticamente, conversamos sobre o texto de Nina e sobre possibilidades de fugir à lógica da dominação. A tensão que se lê a seguir pode ser vista como formas diferentes de aderir ou rejeitar essa lógica.

Nina chamou atenção para o fato de que, na discussão mais ampla na sociedade sobre o funk, "as pessoas criticam o funk como se esperassem que os funkeiros se manifestassem nos mesmos signos e nos nossos padrões. Mas são pessoas diferentes, com estilos de vida diferentes". Ou "com educações diferentes", acrescenta Bia. Continua Nina:

a gente não pode esperar que a música e a cultura oriunda de uma situação diferente funcione nos mesmos padrões que nós queremos pra nossa cultura. As pessoas falam: "que absurdo, eles falam das novinhas, isso é pedofilia". Isso não funciona. Num lugar diferente esse tipo de valor também é diferente. A gente não pode esperar que eles se manifestem do mesmo modo. Uma pessoa de 12 anos na zona sul é uma criança, uma pessoa de 12 anos na Rocinha talvez não seja uma criança. É errado a gente colocar qualquer valor do tipo certo/errado, bem/mal pra cultura.

Uma marcação de diferença é estabelecida na fala de Nina, Bia e na minha. Estamos falando, na zona sul, sobre a música dos morros cariocas. Em jogo está a construção conjunta da diferença cultural. Nina traz à tona uma discussão polêmica em torno do funk, que é a sexualização de menores de idade, as "novinhas". Nina pergunta se a novinha, num contexto como o da Rocinha, é de fato tão criança assim. Não quero discutir se o funk é pedófilo ou não, mas sim apontar que esse foi um marcador de diferença que surgiu na aula - e que teve desdobramentos inesperados. Alex, que se posiciona como evangélico, fez a seguinte observação:

Nessa questão que a Nina falou, eu acho interessante, mas eu concordo e discordo. Concordo que não tem como a gente querer que o mesmo que acontece na zona sul se aplique a outras pessoas. Na música deles, na letra deles. Mas essa questão da novinha, da criança, acho que todo mundo deve ou pode ter esse tipo de entendimento. 
Para Alex, a sexualização de crianças tem de ser vista universalmente como pedofilia. O comentário foi sucedido de um conflito na sala. Imediatamente, os alunos e eu começamos a falar ao mesmo tempo. Tentei transcrever a fala simultânea que emergiu, mas só consegui escutar vários sons superpostos. Sintomaticamente, a única coisa que entendi foi minha própria fala. Referia-me aos "peitinhos de pitomba" na canção Carioca, de Chico Buarque, que pode ser vista como uma menção a uma "novinha". Eis um excerto:

\author{
Cidade Maravilhosa \\ És minha \\ O poente na espinha \\ Das tuas montanhas \\ Quase arromba a retina \\ De quem vê \\ De noite \\ Meninas \\ Peitinhos de pitomba \\ Vendendo por Copacabana \\ As suas bugigangas \\ Suas bugigangas \\ (CHICO BUARQUE, Carioca)
}

O funk e a MPB são práticas musicais com diferentes conotações raciais e geográficas no Brasil. Na discussão que seguiu, alguns alunos não conseguiam ver a sexualização na letra da canção de Chico Buarque, mas viam claramente isso no funk. Transcrevo abaixo a discussão que se seguiu ao conflito inicial:

Sabrina: Eu acho que a sociedade tem que ter uma interseção, e nessa interseção não pode haver um choque tão grande.

Nina: Por que não?

Sabrina: Não pode ter um choque tão grande. Deve haver um modo de dizer. O Chico Buarque pode dizer as coisas de várias maneiras.

Nina: Mas você está julgando as formas de acordo com os seus valores, com sua vida. Você não pode julgar uma manifestação oriunda de um lugar com os valores de outro. Isso é preconceito.

Eu: O Chico Buarque fala nos peitinhos de pitomba.

Xia: São seios de uma menina nova.

Eu: São os seios de uma novinha. E isso não causa crítica/

Alex: Ele fala isso? Mas pode ser também de uma garota adulta de seios pequenos/

Xia: Pelo texto da música, você percebe que é uma menina nova.

Nina: Mas como é Chico Buarque é tido como poesia...

Lia: Mas será que ele fala numa forma de desejo?

Sabrina: Eu acho diferente, porque o Chico Buarque tá falando isso numa música, as pessoas que vão dançar aquela música não vão ficar com os peitos pra fora, pra mostrar que/

Nina: Mas qual é o problema de ficar com o peito pra fora? 


\begin{abstract}
Vanessa: Gente, é o politicamente correto. Cada um tem sua opinião, a gente não pode afetar a opinião de ninguém. A gente tem que se comportar de uma forma que não prejudique nenhum dos lados. Aqui na nossa sala, por exemplo. O Alex tem uma posição, nós temos outra. A gente não tá aqui pra afrontar ninguém. Eu acho que tem certos padrões de comportamento. Eu vivi isso, estudei num colégio que era uma mistura de pessoas. A gente via isso muito claramente. Nas festas, a gente ficava assustado, porque tocavam os funks proibidões e as garotas se abaixavam, ficavam os caras por trás, era uma cena de sexo explícito. No meio de um ambiente que não era pra isso, entende?
\end{abstract}

O pertencimento identitário dos alunos se demarca acima. Sabrina vê como pedofilia a menção às novinhas no funk, mas entende que Chico Buarque, ao falar dos peitinhos de pitomba, não está fazendo o mesmo, porque "pode dizer as coisas de várias maneiras". Na sua visão, a canção de Chico seria constativa (AUSTIN, 1962): os ouvintes apenas "constatariam" o mundo, ninguém colocaria os seios de fora. Já o funk seria performativo: ao escutá-lo, as garotas na escola "se abaixavam, ficavam os caras por trás, era uma cena de sexo explícito". Nina contesta, dizendo que a colega "está julgando as formas de acordo com os seus valores, com a sua vida".

O conflito acima se instaura em torno de "maneiras de dizer" ou "formas linguísticas". Hanks (1996, p.232) defende que "o significado - mesmo o sentido literal - deriva de uma fusão da forma linguística com o contexto". Entendo como contexto as circunstâncias que indexam, imprimem um valor à forma linguística, o que segue centros de poder e adesão diversos (SILVERSTEIN, 2003). Na posição de Sabrina, é como se o funk e a MPB possuíssem mágicas diferentes: o funk performativamente produz sexo explícito, a MPB constativamente produz "um dizer de várias maneiras". A chave para entender a fala de Sabrina, creio, liga-se à vinculação contextual e indexical do funk e da MPB com a ordem racial de poder do Rio. Uma canção de funk indexa um contexto particular, com pigmentações de raça, sexualidade e pertencimento geográfico diferentes de uma canção de Chico Buarque. O ponto de Nina é que não se pode enxergar um signo a partir da indexicalidade de outro contexto, i.e., "julgar as formas do funk de acordo com os seus valores", da classe média branca. Os significados dessa discussão mostram-se, assim, altamente racializados. O que fazer com esse conflito racial em sala de aula? Deixarei que a fala da própria turma aponte uma saída.

Sabrina é uma aluna branca de classe média. Xia é chinesa e mudou para o Rio na infância. Nina é baiana e acabara de mudar para o Rio. Xia e Nina, as alunas diaspóricas, seguem uma linha argumentativa semelhante, recusando-se a enxergar o funk a partir da perspectiva do certo e errado. Xia traz um exemplo de outra 
disciplina: "a gente tava discutindo a questão da culpa que o ser humano carrega. Tudo tem a questão da culpa, você associa a sexualidade à culpa, tudo. Mas a gente tem que se desprender disso." Lia, aluna branca que reivindica um pertencimento à periferia, percebe que precisa ir além dos do certo e do errado:

Eu não tô nem falando certo e errado, mas o funk pra mim tá com uma qualidade questionável. Não acho aquelas letras legais pra uma criança. Mas pra gente dá pra encarar de uma forma bem humorada.

Lia se posiciona também como mãe. É importante lembrar que Alex tem uma filha, então suas marcações identitárias são também de pais que veem o problema nessa perspectiva. Sabrina toma a palavra e afirma:

O problema não é o funk, é um problema social. Não é a criança de 12 anos engravidando, é um problema social. Como é uma sociedade de extremidades muito claras, acho a gente tem que ter um meio termo. Do mesmo jeito que eu sou restringida de andar com joia na rua, eu acho que eles têm que entrar num paralelo com a gente. Você [Bia] mesma não traz seu computador, porque mora longe. A gente se impede de fazer algumas coisas na nossa vida, eu acho que eles também poderiam se aproximar. Senão ficam dois extremos que não têm contato, só têm contato por meio de estudos e essas coisas.

Neste ponto, a fala de Sabrina retorna à sua fala inicial, que reivindicava a necessidade de uma "intersecção, e nessa interseção não pode haver um choque tão grande". No excerto acima ela elabora melhor a questão: assim como ela abre mão de andar com joias na rua e a colega de classe média não traz o computador para a faculdade, eles, os outros, "também têm que entrar num paralelo". Entrar num paralelo seria abrir mão de certos signos de pertencimento racial e geográfico e adotar outros. O problema é que a fala de Sabrina carrega o mesmo ponto que quer rebater: a apartação social. O Rio é marcado por fronteiras simbólicas muito distintas, sendo a geografia uma de suas mais visíveis: embaixo, ricos casarões e edifícios; no alto, casas amontoadas seguindo uma outra dinâmica espacial. Para Sabrina, a violência advém deles, e ela aceita o "contrato" de viver sob o signo da violência, não portando joias; eles, por seu turno, precisariam abrir mão de sua linguagem e de seu comportamento sexualizado, pornográfico em nome de um "paralelo". A convivência pacífica se daria pela via do abandono de signos caros a quem se é - joias, computador ou sexo explícito.

Incomodado, chamei atenção para o conceito de distinção:

Eu: O que é ser erudito, gostar da alta literatura, da alta costura, tudo que é alto?

Diferente do que é baixo, da baixaria, da putaria? Esse bom gosto, Bourdieu vai 
mostrar, é no fundo uma categoria política, é definido numa matriz. De modo que acontece um processo que é a ideia da naturalização.

Xia: Porque pra gente é normal não cuspir no chão, não andar pelado por aí, mas o que é normal? Normal é uma categoria definida pela sociedade. Numa outra sociedade, pros índios, é normal andar pelado.

Xia interveio e associou a distinção à própria noção de normalidade. Em outro momento da aula, respondendo à pergunta que fiz sobre como sair da lógica da dominação, ela chamou atenção para o Manifesto Ciborgue. Citou a figura do ciborgue como um pós-humano, não comprometido com a dominação de gênero. Segundo ela, Haraway "propõe um pós-base. Mas eu não consegui imaginar o que seria o 'pós-isso'. Eu não conseguiria chegar até essa instância." Nina contestou, dizendo que "há pessoas que vivem nesse pós." Xia respondeu: "Sim, tem, mas pra muita gente isso é subversão." Nina responde: "Eu mesma tento viver esse pós na minha vida."

Enfim a subversão se enunciava em sala de aula. Uma aluna reivindicava a diferença tão repugnada pela lógica da dominação macho x fêmea, heterossexual $\mathrm{x}$ homossexual, zona sul x favela. Foi também na fala de Nina que surgiu uma associação entre Lacraia, dançarina do funk carioca, e Divine, a drag queen do filme Female Trouble, que comparece por exemplo no fundamental Gender Trouble de Judith Butler (e a semelhança de títulos não é mera coincidência). Eu comentei que Lacraia subvertia a lógica identitária tradicional porque ela se recusava a ocupar o lugar que lhe teriam dado como homem, negro e favelado. Por exemplo, na canção Caetano disse não, Serginho pergunta a Lacraia: "Quem é essa gatinha que quer ganhar uma canção?" E ela, rebolando, responde: "Meu nome é Luana Piovani".

Numa visão constativa da identidade, o enunciado de Lacraia seria "falso". Mas na presente visão performativa, o enunciado de Lacraia é "feliz", realiza o ato de parodiar e subverter. A sua marcação identitária rompe com a visão representacionista e institui seu modo próprio de comparar. Lacraia parodicamente reivindica a identidade de uma atriz global, branca, mulher, rica. Lia logo lembra que Lacraia é uma das mães da escola onde trabalha. E Nina diz que Lacraia é a "Divine brasileira", a subversão da identidade no Brasil.

\section{PALAVRAS FINAIS}

Os diálogos intermídias foram encontros de sexta à noite entre um professor que buscava trazer a dimensão da crise para a educação e alunos que reagiram, diferentemente, aos diferentes matizes dessa crise. Busquei trazer para o centro 
carioca - a casa de branco - textos que contestavam os significados raciais, sexuais e psíquicos da branquitude hegemônica. Inevitavelmente, posicionamo-nos diante da pragmática e da metapragmática dos discursos oficiais de gênero, sexualidade, raça e da própria educação. A pragmática - o modo como os signos são usados no mundo - e a metapragmática - o modo como os discursos representam esses uso - se vinculam a ordens indexicais (SILVERSTEIN, 2003) que não apenas associam a prática linguística a certos contextos concretos de uso, mas também distribuem desigualmente o capital linguístico. Se é certo que o sujeito fala de algum lugar, vinculando-se a uma ordem indexical, de algum modo tentei chocar esse lugar de onde se fala. Espero que a escrita deste artigo não seja a única consequência daqueles inesquecíveis diálogos de sexta à noite.

\section{REFERÊNCIAS BIBLIOGRÁFICAS}

AUSTIN, J. (1962). How to do things with words. Oxford: Oxford University Press.

DERRIDA, J. (2000). Le toucher, Jean-Luc Nancy. Paris: Galilée. (2002). Torres de Babel. Trad. J. Barreto. Belo Horizonte: Ed. UFMG.

$\overline{\text { FELMAN }}$, S. (2000). Educação e crise, ou as vicissitudes do ensinar. In: Nestroviski, A \& Seligmann, M., (orgs.) Catástrofe e representação. São Paulo: Escuta, pp.13-71.

FREUD, S. (1919a). O inquietante (Das Unbeimliche), trad. P. C. Souza. In: Freud, S., Obras Completas de Sigmund Freud, Vol. 14. São Paulo: Cia das Letras, 2010, pp. 328-376.

. (1919b). Psicanálise das neuroses de guerra. Trad. P. C. Souza. In: Freud, S., Obras Completas de Sigmund Freud, Vol. 14. São Paulo: Cia das Letras, 2010, pp. 382 388 .

(1920). Além do princípio do prazer, trad. P. C. Souza. In: Freud, S., Obras Completas de Sigmund Freud, Vol. 14. São Paulo: Cia das Letras, 2010, pp. 161-239.

HARAWAY, D. (1991). Manifesto ciborgue: ciência, tecnologia e feminismo-socialista no final do século XX. In: Tadeu, T, (org.) Antropologia do ciborgue, trad. T. Tadeu. Belo Horizonte: Autêntica, 2009, pp.33-228.

JAKOBSON, R. (1961). Aspectos linguísticos da tradução. In: Jakobson, R., Linguística e comunicação, trad. I. Blikstein. São Paulo: Cultrix.

LISPECTOR. C. (1998a). A bora da estrela. Rio de Janeiro: Rocco.

(1998b). A paixão segundo G. H. Rio de Janeiro: Rocco.

LOPES, A. (2011). Funk-se quem quiser no batidão negro da cidade carioca. Rio de Janeiro: Bom Texto.

MALABOU, C. (2012). The new wounded: from neurosis to brain damage, trad. S. Miller. New York: Fordham University Press.

NAGIB, L. (2006). A utopia no cinema brasileiro. São Paulo: Cosac Naify.

PLATÃO. (360 A.C.). Sofista. Trad. E. Bini. Bauru: Edipro, 2011.

SILVERSTEIN, M. (2003). Indexical order and the dialectics of the sociolinguistic life. Language \& Communication, v. 23, pp. 33-58. 
SILVERSTEIN, M. (1993). Metapragmatic discourse and metapragmatic function. In: Lucy, J. (org.) Reflexive language: Reported speech and metapragmatics. Cambridge: Cambridge University Press, pp. 193-229.

WERNECK, M.; SUSSEKIND, F.; DACOSTA, A.; ORRICO, E. (2009). Projeto políticopedagógico do curso de Letras. UNIRIO: CLA, 2009.

Recebido: 20/01/2013

Aceito: 21/03/2013 
